\title{
Development and testing of bamboo mat boards
}

\section{S.P. KURHEKAR, S.K. JAIN AND P.P. CHAVAN}

See end of the Paper for authors' affiliation

Correspondence to :

\section{S.P. KURHEKAR}

Department of Farm

Structures, College of Agricultural Engineering and

Technology, Dr. Balasaheb

Sawant Konkan Krishi

Vidyapeeth, DAPOLI (M.S.)

INDIA
- ABSTRACT : Three varieties of bamboo viz., Dedrocalamus ritchy (Manga), Dendrocalamus stocksii (Mes) and Dendrocalamus strictus (Manvel) were used to prepare bamboo mats were weaved manually and treated with glue. Urea formaldehyde (resin) was used as glue to prepare bamboo mat boards. The resin application was done by dipping. Bamboo mats were dipped for 10 min in urea formaldehyde. $30 \mathrm{~kg}$ of resin was required for complete dipping of bamboo mats. Mats were pressed together at $110^{\circ} \mathrm{C}$ temperatures and pressure of $150 \mathrm{~kg} / \mathrm{cm}^{2}$ was applied for 5 min. This is for spreading glue properly. Mats were again pressed at $110^{\circ} \mathrm{C}$ at a pressure of $200 \mathrm{~kg} / \mathrm{cm}^{2}$ for $10 \mathrm{~min}$ to from bamboo mat boards. Boards were trimmed to a size of $2.1 \mathrm{~m} \times 1.2 \mathrm{~m}$ board of $9 \mathrm{~mm}$, $12 \mathrm{~mm}$ and $16 \mathrm{~mm}$ thickness were prepared. Bamboo mat board can be prepared from Dendrocalamus stocksii (Mes), Dedrocalamus ritchy (Manga) and Dendrocalamus strictus (Manvel) using urea formaldehyde resin. Dedrocalamus ritchy (Manga) was easy to prepare slivers of bamboo. Density of bamboo mat board increased as thickness increases. Maximum density was for Dendrocalamus stocksii (Mes). Water absorption bamboo mat board decreased as thickness increases and was minimum for Dendrocalamus stocksii (Mes). Tensile strength and compressive strength for bamboo mat board increased as thickness increases. For Dendrocalamus stocksii (Mes) maximum tensile strength and maximum compressive strength was $37.83,43.21$ and $48.50 \mathrm{~N} / \mathrm{mm}^{2}$ and $15.75,19.21$ and $26.30 \mathrm{~N} / \mathrm{mm}^{2}$ for 9,12 and $16 \mathrm{~mm}$ thickness, respectively.

- KEY WORDS : Bamboo mat board, Bamboos

- HOW TO CITE THIS PAPER : Kurhekar, S.P., Jain, S.K. and Chavan, P.P. (2015). Development and testing of bamboo mat boards. Internat. J. Agric. Engg., 8(2) : 261-264. 